\title{
KONDISI TERUMBU KARANG DI KEPULAUAN SERIBU DALAM KAITAN DENGAN GRADASI KUALITAS PERAIRAN
}

\section{WATER QUALITY GRADATION OF CORAL REEF AT SERIBU ISLAND}

\author{
Ruswahyuni dan Pujiono Wahyu Purnomo \\ Fakultas Perikanan dan Ilmu Kelautan \\ Universitas Diponegoro \\ Jl. Tembalang Semarang 50275
}

\begin{abstract}
The increasing of Jakarta land activies caused eutrophication, so that it changes species composition and decreasing of number of species. The sea within the high of eutrophication has correlation with the high growth of alga, depletion of oxygen and change of coral species composition. These researchs was done at coral reef ecosystem of Lancang Island, Pari Island and Payung Island, whereas there are part of Seribu Island Cluster.

The aims of research was evaluating of nutrient enrichment effect to morphology and functional of coral reef condition. Morphology figures are showed by basic cover, whereas functional aspects are evaluated by zooxanthellae density.

The results are showed that the high eutrophication is significantly correlated with main land of Java Island distance. The increasing of nutrient enrichment is significantly to change profile of coral reef and zooxanthellae densities.
\end{abstract}

Keywords : coral reef, Seribu Island, water quality gradation

\section{Pendahuluan}

Pertumbuhan hewan karang herrnatipik terbatas pada kondisi cahaya yang cukup untuk terjadinya proses fotosintesis zooxantella, selain itu ditunjang dengan kondisi fisik antara lain arus, kedalaman, kekeruhan dan sedimentasi, serta aspek ekologis lain seperti siklus hari, suhu, konsentrasi plankton, predator, serta kompetisi dengan beberapa organisme lainnya termasuk jenis hewan karang lainnya (Stoddart, 1973). Hewan karang dapat bertahan hidup pada kisaran suhu antara $18-36^{\circ} \mathrm{C}$ dengan suhu optimal untuk pertumbuhan adalah $26-28^{\circ} \mathrm{C}$ (Weber and White, 1974 di dalam Birkeland, 1997. Perubahan suhu yang ekstrim akan menyebabkan kerusakan seperti terhambatnya reproduksi bahkan bisa terjadi bleaching. Terjadinya kasus bleaching pada suhu yang tinggi terjadi karena lepasnya zooxantella dari jaringan karang. Sedangkan kisaran salinitas untuk kehidupan hewan karang berkisar antara 33 - 36\%o. Dalam kondisi dibawah kisaran tersebut maka pemanfaatan carbonat di air akan didominasi oleh kelompok vermetid, oyester dan alga kapur (Heckel, 1974 di dalam Birkeland, 1997.

Beberapa aspek yang dapat menyebakan kematian hewan karang adalah dari aspek biologis, fisik dan kimia. Secara biologis kematian dapat terjadi karena pemangsaan oleh beberapa spesies, serta adanya proses bioerosi yang dilakukan oleh beberapa jenis organisme yang hidup dalam ekosistem. Hewan yang memangsa hewan karang adalah Acanthaster planci dan Drupela sp. Sedangkan yang melakukan bioerosi adalah dari kelompok tumbuhan rendah seperti bakteri, filmentous algae yang masuk kedalam jaringan karang, selain itu juga dari kelompok fungi, sponge, polychaeta, crustasea, sipuncula dan molusca. Sebagai contoh yang terjadi di perairan Atlantik Barat, jenis sponge, diona, anthosigmella hidup dengan membor jaringan karang hingga kedalaman 5 - $15 \mathrm{~mm}$ bahkan ada yang mencapai $12 \mathrm{~cm}$. Dari aspek fisik, kerusakan terjadi karena beberapa hal, seperti adanya gelombang yang besar akan memporakporanda terumbu karang, adanya peningkatan suhu akan menyebabkan bleaching, seperti yang terjadi dalam kasus EINino yang dilaporkan oleh Birkeland (1997), bahwa pada tahun 1982-1983 terjadi kematian hingga 5099\% di perairan Pasifik Timur. Sedangkan kematian hewan karang yang disebabkan oleh aspek kimiawi adalah adanya polutan yang masuk dari aktivitas manusia di daratan yang menyebabkan eutrofikasi, sedimentasi, polusi serta masuknya air tawar yang berlebihan dari darat karena terjadi erosi melalui proses runoff. 
Gugusan pulau-pulau kecil di kawasan Kepulauan Seribu pada umumnya mempunyai penutupan karang di sepanjang garis pantainya. Dalam proses pertumbuhan dan perkembangannya, kawasan ini mengalami pengaruh yang sangat kuat dari aktivitas Pulau Jawa khususnya di daerah Jakarta melalui run off. Run off ini pada umumnya membawa berbagai material terlarut ke dalam Iingkungan perairan yang dapat menyebabkan penyuburan berlebihan (eutrifikasi). Karang memerlukan kualitas perairan yang sangat bersih pada ekosistem pesisir tempat ia berada dan akan kesulitan jika terjadi sebaliknya. Salah satu aspek krusial dari kualitas air adalah konsentrasi nutrien di dalam perairan. Nutrien adalah elemen yang dibutuhkan untuk pertumbuhan semua makhluk hidup dan bila mereka tidak tersedia dengan cukup, maka organisme tidak akan mampu untuk tumbuh dengan baik. Terumbu karang adalah ekosistem yang memerlukan nutrien lingkungan dengan konsetrasi rendah. Kondisi nutrien yang kaya di perairan akan membahayakan karang karena kekuatan kompetisinya dalam memanfaatkan ruang yang diperkirakan lebih lemah dibandingkan dengan dengan perkembangan makroalgae. Nitrogen yang tersedia secara biologi (nitrat tambah ammonia) yang baik untuk kehidupan karang adalah di bawah 1,0 $\mu \mathrm{M} \mathrm{L}^{-1}$ (kurang dari 0,014 ppm nitrogen), dan fosfor yang tersedia secara biologi (orthofosfat tambah dissolved organic phosphorus, DOP) di bawah $0,1 \mu \mathrm{M} \mathrm{L}^{-1}$ (kurang dari 0,003 ppm fosfor) (Damar, 2003). Di lain pihak hasil penelitian Edy dan Pujiono (2004) menunjukkan

bahwa di kawasan Perairan Pulau Lancang mempunyai kadar nitrogen tersedia secara biologi sebesar $0,1324 \mathrm{mg} / \mathrm{I}$ dan orthofosfat sebesar $0,0122 \mathrm{mg} / 1$. Nilai ini jauh lebih tinggi dibandingkan dengan batasan kebutuhan biolgi karang.

Peningkatan pembangunan di daratan dengan kecenderungan yang meningkat diperkirakan mempunyai korelasi dengan peningkatan pengkayaan wilayah perairan pulau seribu. Dalam rangka mengembangkan batasan terhadap peningkatan polutan ini maka penelitian mengenai efek nutrien terhadap karang perlu dilakukan. Penelitian yang dilaksanakan di sisi sebelah pulau Lancang, Pari dan Payung sebagai representasi kawasan yang terkena pengaruh gradasi pengkayaan nutrient dari Jakarta ditujukan untuk mengevaluasi efek pengkayaan nutrient terhadap kondisi terumbu karang baik diri sisi tampilan morfologinya maupun dari aspek fungsionalnya. Tampilan morfologinya disajikan dari tutupan dasar, sedangkan aspek fungsionalnya dievaluasi berdasarkan densitas zooxanthellaenya.

\section{Materi dan Metode Penelitian}

Penelitian ini dilaksanakan di gugus pulau depan ekosistem terumbu karang Kepulauan Seribu Provinsi DKI Jakarta (Gambar 1).

Penilaian kondisi terumbu karang di Pulau Lancang, Pulau Pari dan Pulau Payung, dilakukan dengan menggunakan metode

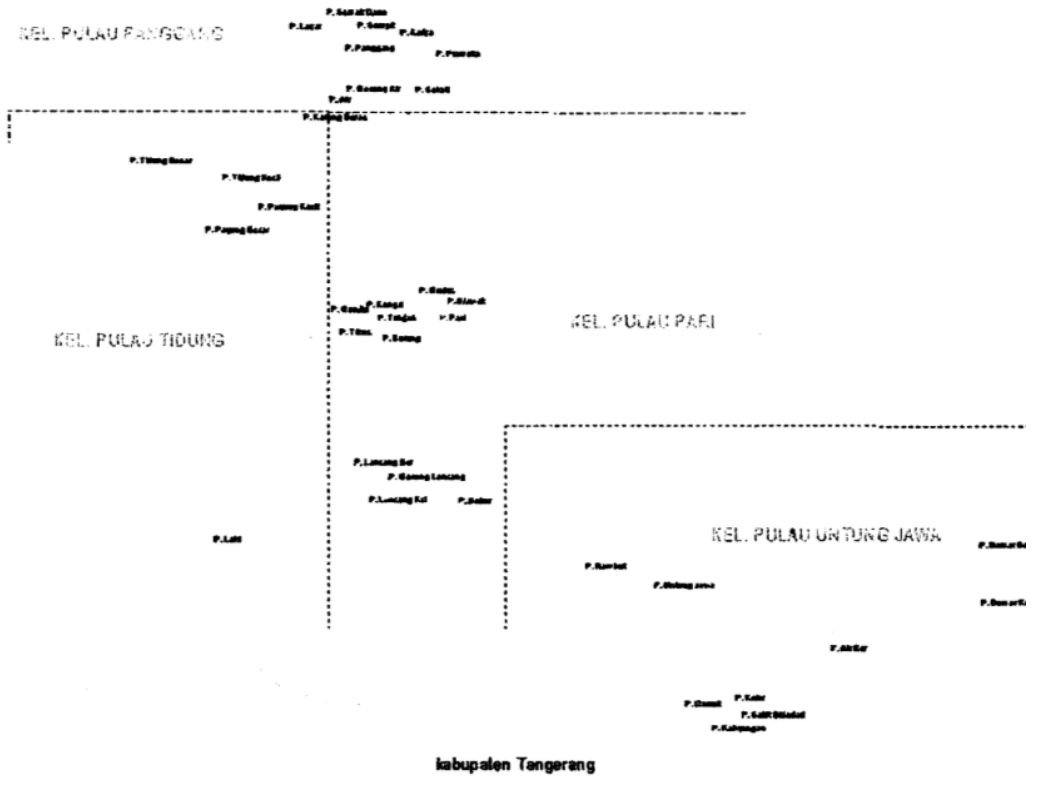

Gambar 1. Lokasi penelitian di Ekosistem Terumbu Karang Kepulauan Seribu DKI Jakarta 
transek garis (line intercept transect, LIT) berdasarkan bentuk pertumbuhan (life form) karang (English et al., 1997). Pengukuran kondisi terumbu karang dengan metode ini dimulai dengan pemilihan tapak yang memungkinkan pada lereng terumbu serta dilakukan pada kedalaman optimum yaitu 3 meter. Untuk setiap tempat dilakukan pengamatan terhadap dua transek yang masingmasing panjangnya $30 \mathrm{~m}$ (Gambar 2). Untuk mengetahui kondisi terumbu karang, selanjutnya dilakukan penghitungan persentase penutupan (percent of cover) bagi masingmasing kategori bentuk pertumbuhan dengan cara membandingkan panjang total setiap kategori dengan panjang total transek. Hasil persentase penutupan dapat dijadikan sebagai penentu kondisi terumbu karang. Bila luas tutupan terumbu karang hidup berkisar dari 0$24,9 \%$ maka digolongkan sebagai kondisi buruk; 25-49,9\% adalah sedang; 50-74,9\% baik; dan 75-100\% adalah baik sekali (English et al., 1997).

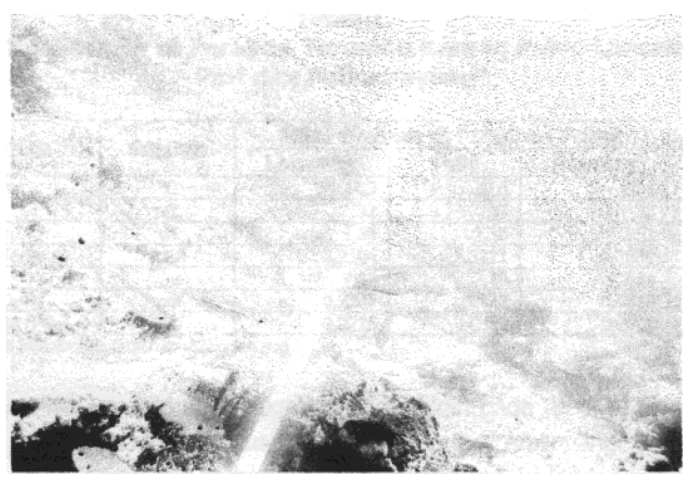

Gambar 2. Pengamatan kondisi terumbu karang dengan metode LIT

Analisis Densitas zooxanthellae dilakukan pada jenis dominan yang ditemukan dari hasil kajian penutupan karang. Dengan cara mengambil sebagian contoh pada luasan permukaan sebesar $2 \times 2 \mathrm{~cm}$. Contoh ini kemudian ditambah dengan $10 \mathrm{ml}$ air laut dan diblender; dilanjutkan dengan centrifuge dengan kecepatan $2500 \mathrm{rpm}$. Cairan supernatan yang berada di bagian permukaan merupakan konsentrat berisi zooxanthellae. Cairan ini kemudian dipisahkan dengan penambahan larutan MAF 1\% untuk selanjutnya diukur kelimpahannya dengan mempergunakan metoda mikroskopik. Di samping data tersebut juga diukur beberapa peubah air di tiga lokasi, yang mencakup: salinitas, suhu, oksigen terlarut, kecerahan, nitrat dan orthofosfat.

Evaluasi terhadap hasil pengukuruan tutupan dasar dan densitas zooxanthellae antar lokasi mempergunakan uji analisis variance (uji F) dengan bantuan software

Exelstat. Adapun kualitas air dikaji secara dekriptif. Hubungan antara peubah kualitas air dan kondisi tutupan karang maupun densitas zooxanthellae dikaji dengan analisis regresi. Perhitungannya mempergunakan bantuan software Exelstat.

\section{Hasil dan Pembahasan}

Terumbu karang adalah ekosistem yang memerlukan nutrien Iingkungan dengan konsentrasi rendah (oligotrofik), karena nutrien yang berlebih seringkali dimanfaatkan oleh makro alga untuk tumbuh berlebihan (overgrowth) sehingga terjadi penaungan (overshading) terhadap karang. Dengan demikian, nutrien yang kaya di perairan (perairan eutrofik) akan membahayakan karang dan bahkan mampu membunuh terumbu karang (McCook et al., 2001). Dalam hal ini kondisi beberapa peubah kualitas air yang terukur pada perairan studi adalah sebagaimana disajikan pada Tabel 1.

Hasil analisis kualitas air sebagaimana disajikan pada tabel di atas menunjukkan bahwa semua peubah kecuali nitrat dan orthofosfat yang memperlihatkan perbedaan. Kadar nitrat dan orthofosfat memperlihatkan kecenderungan meningkat ke arah main land (Jakarta). Kadar

Tabel 1. Analisis Kualitas Air di Perairan Terumbu Karang Pulau Lancang, Pulau Pari dan Pulau Payung*

\begin{tabular}{|c|c|c|c|c|c|c|}
\hline \multirow{2}{*}{ No } & \multirow{2}{*}{ Peubah } & \multirow{2}{*}{ Satuan } & \multicolumn{3}{|c|}{ Nilai Peubah di Perairan Pulau } & \multirow{2}{*}{ Keterangan } \\
\hline & & & Lancang & Pari & Payung & \\
\hline 1 & Temperatur & ${ }^{\circ} \mathrm{C}$ & 28,5 & 28,6 & 28,4 & \\
\hline 2 & Salinitas & $\mathrm{ppt}$ & 32 & 33 & 33 & \\
\hline 3 & Kecerahan & $\mathrm{m}$ & 1,88 & 2,38 & 2,51 & \\
\hline 4 & Oksigen Terlarut & $\mathrm{mg} / \mathrm{l}$ & 52,104 & 53,211 & 52,839 & \\
\hline 5 & $\mathrm{pH}$ & & 7,26 & 7,18 & 7,21 & \\
\hline 6 & Nitrat $\left(\mathrm{NO}_{3}-\mathrm{N}\right)$ & $\mathrm{mg} / \mathrm{l}$ & 0,2307 & 0,0622 & 0,0316 & $0,014 * *)$ \\
\hline 7 & Orthofosfat $\left(\mathrm{PO}_{4}\right)$ & $\mathrm{mg} / \mathrm{l}$ & 0,0216 & 0,0084 & 0,0069 & $0,003 * *)$ \\
\hline
\end{tabular}

*) data diukur pada kedalaman dasar terumbu karang

**) Damar, 2003 
tersebut baik yang dekat (Pulau Lancang) maupun yang terjauh (Pulau Payung) masih di atas kadar optimal karang sebagaimana diberikan oleh (Damar, 2003).

Kondisi terumbu karang yang ada di sekitar lokasi penelitian juga akan sangat mempengaruhi rekruitmen karang di lokasi penelitian, terutama dalam hubungan sumber dan 'penenggelaman' larva (source-sink relationship). Apalagi mengingat Kepulauan Seribu mempunyai karakteristik dan keunikan tersendiri ditinjau dari aspek oseanografi, terutama dengan dominannya pengaruh angin musim (Wirtky, 1961). Menurut Potts (2002) komunitas lokal yang sudah mantap dan dinamika populasi dapat mempunyai efek sangat penting dalam pola rekruitmen karang. Untuk tujuan ini, maka telah dilakukan pengamatan terhadap kondisi terumbu karang di Pulau Pari, Pulau Lancang dan Pulau payung yang hasilkan disajikan pada Gambar 3.

Secara umum hasil yang diperoleh antara ketiga lokasi yang diamati rnemperlihatkan hasil yang berbeda. Menurut English et al (1997), persentase penutupan karang batu yang terdiri dari hard coral (Acropora) dan hard coral (non-Acropora) merupakan acuan dalam menentukan kondisi terumbu karang. Dari hasil yang didapatkan,

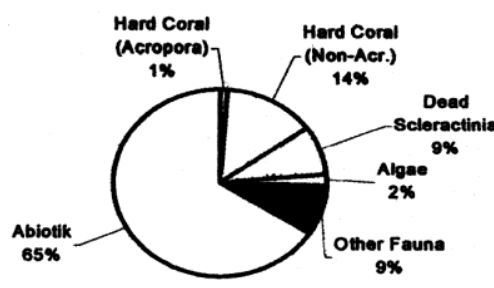

a

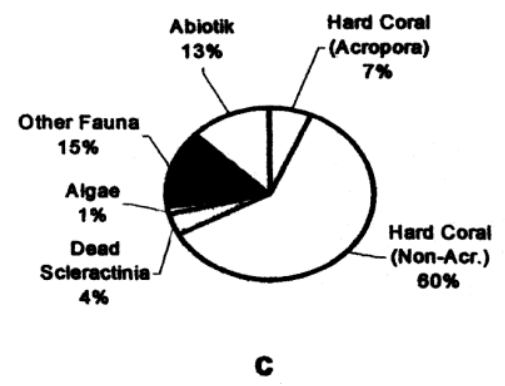

maka terurnbu karang di Pulau Lancang dengan persentase penutupan karang batu 15\% masuk dalam kategori rusak; Pulau Pari dengan persentase penutupan karang batu 36\% masuk dalam kategori sedang, dan; Pulau Payung dengan persentase penutupan karang batu $67 \%$ masuk dalam kategori baik.

Hasil yang diperoleh menunjukkan bahwa penutupan karang batu semakin rneningkat dengan semakin jauh dari daratan utama, Pulau Jawa. Mengingat bahwa selama penelitian dilakukan adalah musim timur, dimana pola arus yang terjadi secara urnum adalah dari Tenggara menuju Barat Laut (Wirtky, 1961), maka kernungkinan rekrutmen karang di Pulau payung relatif lebih rendah dibandingkan musim lainnya sepanjang tahun karena sumber larva karang dibawa oleh arus permukaan laut dari wilayah yang kondisi terumbu karangnya jelek dan sedang, namun untuk membuktikan hal ini perlu dilakukan penelitian tahunan.

Selain melihat kondisi terumbu karang, dilakukan juga uji-t terhadap bentuk hidup organisme benthik antar ketiga lokasi terumbu karang yang diamati untuk mendapatkan gambaran lebih detail. Hasil yang ditampilkan pada Tabel 2 memperlihatkan bahwa perbedaan yang nyata terjadi antara

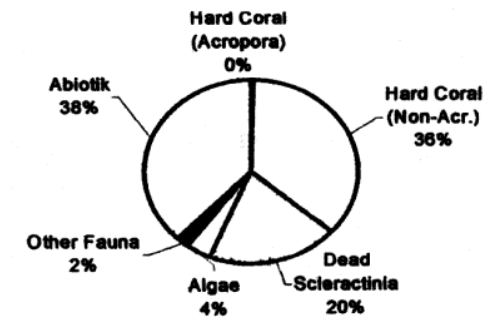

b

Gambar 3. Persentase Bentuk Hidup (life form) Oragnisme Benthik di Masing-masing Stasiun; a. Pulau Lancang; b. Pulau Pari, dan; c. Pulau Payung. 
Tabel 2. Uji-t bentuk hidup (life form) organisme benthik

\begin{tabular}{|c|l|c|c|c|}
\hline \multirow{2}{*}{ No } & \multicolumn{1}{|c|}{ Bentuk Hidup } & \multicolumn{3}{|c|}{ Uji-t } \\
\cline { 3 - 5 } & & Lancang-Pari & Pari-Payung & Lancang-Payung \\
\hline $\mathbf{1}$ & Hard Coral (Acropora) & $\mathrm{ns}$ & $\mathrm{ns}$ & $\mathrm{ns}$ \\
2 & Hard Coral (Non-Acropora) & $\mathrm{ns}$ & $\mathrm{ns}$ & $*$ \\
3 & Dead Scleractinia & $\mathrm{ns}$ & $\mathrm{ns}$ & $\mathrm{ns}$ \\
4 & Algae & $\mathrm{ns}$ & $\mathrm{ns}$ & $\mathrm{ns}$ \\
5 & Other Fauna & $\mathrm{ns}$ & $\mathrm{ns}$ & $\mathrm{ns}$ \\
6 & Abiotic & $\mathrm{ns}$ & $\mathrm{ns}$ & $*$ \\
\hline
\end{tabular}

keterangan: ns tidak berbeda nyata; * berbeda nyata

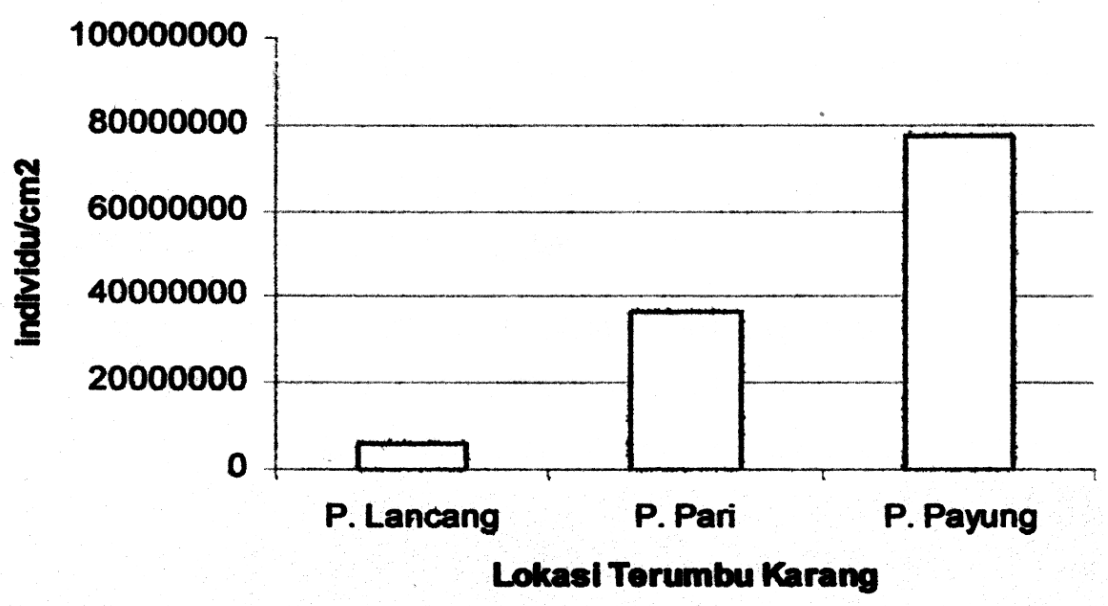

Gambar 4. Densitas Zooxanthellae Rata-rata pada Jenis Karang Goniastrea Sp di Perairan Terumbu Karang Wilayah Kajian

Pulau Lancang dengan Pulau Payung untuk kategori hard coral (Non-Acropora) dan abiotic. Hal ini menunjukkan bahwa bentuk hidup organisme benthik sangat berbeda antara kedua lokasi, yaitu Pulau Lancang didominasi oleh bentuk hidup abiotic (65\%), sedangkan Pulau payung didominasi oleh bentuk hidup hard coral (non-Acropora) (60\%) (Gambar 3).

Sebagaimana halnya dengan kondisi tutupan karang hidup, maka secara fungsional diperlihatkan profil sebaran densitas zooxanthellae berdasarkan letak pulau. Dalam hal ini jenis dominant adalah Goniastrea dengan hasil telaah bahwa semakin mendekat dengan pulau utama (Jawa) semakin tipis densitas zooxanthellae yang ada (Gambar 4).

Dari hasil uji regresi terhadap hubungan antara densitas zooxanthellae dengan kadar nitrat diperoleh keterangan bahwa secara nyata didapatkan korelasi negative dengan model perubahan : $\mathrm{Y}=70176237-2,8 \times 10^{8} \mathrm{X}$ $(\mathrm{R}=0,85)$. Demikian pula dengan hubungan antara densitas zooxanthellae dengan kadar orthofosfat; dengan model perubahan : $\mathrm{Y}=$
$82077523-3,9 \times 10^{9} \times(\mathrm{R}=0,81)$.

Meskipun telah lama dijelaskan mengenai kepentingan alga terhadap terumbu karang yang baik dan yang mengalami degradasi, namun informasi mengenai distribusi alga di suatu ekosistem terumbu karang sangat kurang dan jarang dipelajari, khususnya di ekosistem terumbu karang yang mengalami degradasi. McCook dan Price (1997) mengungkapkan bahwa diperoleh fenomena yang tidak umum, yaitu berlimpahnya alga di bagian dekat pantai (inshore) terumbu karang pinggir di Great Barrier Reef, namun data sejarah dan penyebab yang mampu menjelaskannya sangat kurang, baik mengenai gambaran distribusi alga maupun hal belum terungkapkan yang mempunyai implikasi penting untuk para pengelola terumbu karang dan pihak terkait.

Kompetisi antara alga benthik dengan karang adalah proses kunci dalam ekologi komunitas dari terumbu, khususnya selama degradasi terumbu. Namun, terdapat hanya sedikit uji eksperimen yang mempelajari kompetisi antara karang dan alga benthik, 
meskipun secara luas diasumsikan bahwa alga umumnya adalah kompetitor superior terutama pada kondisi yang eutrofik. McCook (2001) telah melakukan pengujian untuk melihat kompetisi terhadap ruang antara karang massive jenis Porites lobata dan filamentous alga di tiga terumbu sepanjang gradien cross-shelf dari pengaruh daratan melalui pembuangan atau merusak salah satu karang atau alga. Hasilnya menunjukkan bahwa alga dan karang berkompetisi terhadap ruang, namun alga terlihat secara signifikan mempunyai efek yang ked I terhadap pertumbuhan karang. Sebaliknya karang Porites lobata secara signifikan menghalangi pertumbuhan alga, yang menunjukkan bakwa karang tersebut adalah kompetitor superior. Hal ini tidak mendukung argumen sebelumnya bahwa alga adalah kompetitor yang lebih sukses di kondisi Iingkungan yang lebih eutrofik. Hasil penting lainnya adalah pertumbuhan karang yang umumnya positif, meskipun di kawasan terumbu dengan pengaruh daratan paling besar.

Kompetisi antara karang dengan alga kemungkinan sudah sangat luas di terumbu karang dengan melibatkan sejumlah interaksi. Pergantian secara luas karang oleh alga sering mengindikasikan karena gangguan eksternal, tidak hanya akibat kompetisi overgrowth, namun juga sampai pada penghambatan kompetitif rekruimen karang dengan konsekuensi terhalangnya pemulihan terumbu karang. McCook et al. (2001) mencatat ada delapan proses spesifik yang terjadi dalam interaksi karang dan alga yang saling mempengaruhi satu sama lainnya dan mengusulkan sifat-sifat sejarah hidupnya yang mungkin mempengaruhi interaksi tersebut. Suatu matriks pengaruh alga terhadap karang dengan proses-proses yang mungkin untuk masing-masing kombinasi bentuk hidup karang dengan kelompok fungsional alga yang memperlihatkan suatu framework awal untuk menambah pemahaman dan interpretasi dalam interaksi karang-alga (Tabel 3).

Degradasi terumbu karang seringkali melibatkan suatu "pergantian fase" dari karang yang berlimpah kepada makroalga berlimpah. McCook (1999) menyimpulkan bahwa nutrient overload dapat berkontribusi terhadap degradasi terumbu karang, namun hal ini belum dapat menjadi fase pergantian secara sederhana melalui peningkatan laju pertumbuhan makroalga dan akibatnya overgrowth terhadap karang, kecuali kalau herbivora tidak seperti biasanya atau sedikit. Konsentrasi dari nutrien organik terlarut adalah indikator yang jelek untuk kondisi terumbu karang, dan konsep dari konsentrasi ambang yang mengindikasikan eutrofikasi mempunyai sedikit validitas.

Tabel 3. Matriks mekanisme interaksi kompetitif antara grup fungsional alga dan bentuk hidup karang (McCook et al. 2001)

\begin{tabular}{|c|c|c|c|c|c|c|c|c|}
\hline Grup fungsional & & & & Bentuk h & ip karang & & & \\
\hline Alga & Brancing & Digitate & Tubulate & Encrusting & Foliose & Massive & Mushroo & Recruits \\
\hline Mikroalga & $\begin{array}{l}\mathrm{O} ; \mathrm{C} \\
-\end{array}$ & $\begin{array}{l}\mathrm{O} ; \mathrm{C} \\
-\end{array}$ & $\begin{array}{l}\mathrm{O} ; \mathrm{C} \\
-\end{array}$ & $\mathrm{O} ; \mathrm{C}$ & $\mathrm{O} ; \mathrm{C}$ & $\begin{array}{l}\mathrm{O} ; \mathrm{C} \\
-\end{array}$ & $\mathrm{O} ; \mathrm{C}$ & $\begin{array}{l}\mathrm{O} ; \mathrm{C} \\
-\end{array}$ \\
\hline Filamentous & $\overline{\mathrm{O}} ; \mathrm{C}$ & $\overline{\mathrm{O}} ; \mathrm{C}$ & $\overline{\mathrm{O}} ; \mathrm{C}$ & $\overline{\mathrm{O}} ; \mathrm{C}$ & $\mathrm{O} ; \mathrm{C}$ & $\overline{\mathrm{O}} ; \mathrm{C}$ & - & $\begin{array}{l}\mathrm{O} \\
\mathrm{S} ; \mathrm{A} ; \mathrm{P}\end{array}$ \\
\hline Foliose & $\begin{array}{l} \\
\end{array}$ & $\bar{O}$ & O & $\begin{array}{l}0 \\
- \\
\end{array}$ & $\begin{array}{l}\mathrm{O} \\
- \\
\end{array}$ & $\overline{\mathrm{O}}$ & $\overline{\mathrm{O}}$ & $\mathrm{O} ; \mathrm{S} ; \mathrm{P}$ \\
\hline $\begin{array}{l}\text { Upright corticated } \\
\text { foliose }\end{array}$ & $\overline{\mathrm{O}} ; \mathrm{A}$ & $\overline{\mathrm{O}} ; \mathrm{A}$ & $\bar{O}$ & $\begin{array}{l}\mathrm{O} \\
-\end{array}$ & $\begin{array}{l}\mathrm{O} \\
\mathrm{A}\end{array}$ & $\begin{array}{l}\mathrm{O} \\
\mathrm{A}\end{array}$ & $\overline{\mathrm{O}} ; \mathrm{A}$ & $\mathrm{O} ; \mathrm{S} ; \mathrm{P}$ \\
\hline $\begin{array}{l}\text { Creeping corticated } \\
\text { foliose }\end{array}$ & $\begin{array}{l}0 \\
-\end{array}$ & $\overline{\mathrm{O}}$ & - & O & $\begin{array}{l}\mathrm{O} \\
-\end{array}$ & $\overline{\mathrm{O}}$ & $\overline{\mathrm{O}}$ & $\mathrm{O} ; \mathrm{S} ; \mathrm{P}$ \\
\hline $\begin{array}{l}\text { Corticated } \\
\text { macrophytes }\end{array}$ & $\begin{array}{l}- \\
\mathrm{O} ; \mathrm{A}\end{array}$ & $\begin{array}{l}- \\
A\end{array}$ & A & $\begin{array}{l}\mathrm{A} \\
\mathrm{O}\end{array}$ & $\begin{array}{l}\mathrm{A} \\
\mathrm{O}\end{array}$ & $\begin{array}{l}\mathrm{A} \\
\mathrm{O}\end{array}$ & $\begin{array}{l}\mathrm{A} \\
\mathrm{O}\end{array}$ & $\begin{array}{l}\mathrm{O}: \mathrm{A}: \\
-\end{array}$ \\
\hline $\begin{array}{l}\text { Leathery } \\
\text { macroDhvtes }\end{array}$ & $\begin{array}{l}\mathrm{S} \\
\mathrm{O} ; \mathrm{A}\end{array}$ & $\begin{array}{l}\mathrm{S} \\
\mathrm{A}\end{array}$ & $\begin{array}{l}\mathrm{S} \\
\mathrm{A}\end{array}$ & $\begin{array}{l}\mathrm{S} ; \mathrm{A} \\
\mathrm{O}\end{array}$ & $\mathrm{S} ; \mathrm{A}$ & $\begin{array}{l}\mathrm{S} ; \mathrm{A} \\
\mathrm{O}\end{array}$ & $\begin{array}{l}\mathrm{S} \\
-\end{array}$ & $\mathrm{R} ; \mathrm{A}$ \\
\hline $\begin{array}{l}\text { Articulated } \\
\text { calcareous }\end{array}$ & - & $\overline{\mathrm{O}}$ & $\overline{\mathrm{O}}$ & O & O & O & $\overline{\mathrm{O}}$ & $\mathrm{O} ; \mathrm{S} ; \mathrm{P}$ \\
\hline Crustose & $\begin{array}{l} \\
\mathrm{S} \\
\end{array}$ & $\overline{\mathrm{O}}$ & $\overline{\mathrm{O}}$ & $\begin{array}{l}\mathrm{O} \\
- \\
\end{array}$ & $\overline{0}$ & $\overline{0}$ & $\overline{0}$ & $\mathrm{O} ; \mathrm{SI}$ \\
\hline
\end{tabular}

Keterangan: masing-masing sel dengan dua baris, baris pertama mengindikasikan mekanisme kompetitif diusulkan yang mungkin atau proses yang umum dan baris kedua mengindikasikan proses yang diusulkan terjadi namun tidak penting atau kurang umum, 0 overgrowth; $\mathrm{S}$ shading; A abrasion; $\mathrm{C}$ chemical; $P$ pre-emption; $R$ redruitment barrier; SI epithelial sloughing;- no mechanism applicable 
Persentase Penutupan Bentuk Hidup Benthik di Tiap Lokasi Pengamatan

\begin{tabular}{|c|c|c|c|c|c|c|c|c|c|c|c|c|c|}
\hline \multirow{3}{*}{ Bentuk Hidup } & \multirow{3}{*}{ Kode } & \multicolumn{12}{|c|}{ Persentase Penutupan (\%) } \\
\hline & & \multicolumn{4}{|c|}{ P. Lancang } & \multicolumn{4}{|c|}{ P. Pari } & \multicolumn{4}{|c|}{ P.Payung } \\
\hline & & 1 & 2 & 3 & $\mathrm{X}$ & 1 & 2 & 3 & $\mathrm{X}$ & 1 & 2 & 3 & $\mathrm{X}$ \\
\hline Hard Coral (Acropora) & & 0.0 & 0.0 & 3.3 & 1.1 & 0.0 & 0.0 & 1.0 & 0.3 & 2.0 & 6.0 & 12.2 & 6.7 \\
\hline Branching & $\mathrm{ACB}$ & 0.0 & 0.0 & 0.0 & 0.0 & 0.0 & 0.0 & 1.0 & 0.3 & 2.0 & 0.0 & 5.6 & 2.5 \\
\hline Tabulate & $\mathrm{ACT}$ & 0.0 & 0.0 & 3.3 & 1.1 & 0.0 & 0.0 & 0.0 & 0.0 & 0.0 & 6.0 & 3.9 & 3.3 \\
\hline Encrusting & $\mathrm{ACE}$ & 0.0 & 0.0 & 0.0 & 0.0 & 0.0 & 0.0 & 0.0 & 0.0 & 0.0 & 0.0 & 2.1 & 0.7 \\
\hline Submassive & ACS & 0.0 & 0.0 & 0.0 & 0.0 & 0.0 & 0.0 & 0.0 & 0.0 & 0.0 & 0.0 & 0.0 & 0.0 \\
\hline Digitate & ACD & 0.0 & 0.0 & 0.0 & 0.0 & 0.0 & 0.0 & 0.0 & 0.0 & 0.0 & 0.0 & 0.6 & 0.2 \\
\hline Hard Coral (Non Acr.) & & 21.5 & 12.5 & 7.4 & 13.8 & 21.5 & 53.3 & 33.3 & 36.0 & 69.8 & 43.5 & 67.6 & 60.3 \\
\hline Braching & $\mathrm{CB}$ & 14.5 & 0.0 & 3.6 & 6.0 & 1.5 & 20.0 & 10.8 & 10.8 & 61.8 & 7.5 & 38.6 & 35.9 \\
\hline Massive & $\mathrm{CM}$ & 0.0 & 12.5 & 0.9 & 4.5 & 2.5 & 1.5 & 4.9 & 3.0 & 0.0 & 0.0 & 4.5 & 1.5 \\
\hline Encrusting & $\mathrm{CE}$ & 0.0 & 0.0 & 0.8 & 0.3 & 5.0 & 0.0 & 1.1 & 2.0 & 0.0 & 0.0 & 7.1 & 2.4 \\
\hline Submassive & CS & 0.0 & 0.0 & 0.0 & 0.0 & 0.0 & 2.5 & 0.0 & 0.8 & 0.0 & 0.0 & 3.7 & 1.2 \\
\hline Foliose & $\mathrm{CF}$ & 7.0 & 0.0 & 0.0 & 2.3 & 10.0 & 26.0 & 12.4 & 16.1 & 8.0 & 36.0 & 9.7 & 17.9 \\
\hline Mushroom & CMR & 0.0 & 0.0 & 0.0 & 0.0 & 2.5 & 3.3 & 4.1 & 3.3 & 0.0 & 0.0 & 4.0 & 1.3 \\
\hline Millepora & CME & 0.0 & 0.0 & 2.1 & 0.7 & 0.0 & 0.0 & 0.0 & 0.0 & 0.0 & 0.0 & 0.0 & 0.0 \\
\hline HeliOE-0ra & CHL & 0.0 & 0.0 & 0.0 & 0.0 & 0.0 & 0.0 & 0.0 & 0.0 & 0.0 & 0.0 & 0.0 & 0.0 \\
\hline Dead Scleractinia & & 3.0 & 6.5 & 16.3 & 8.6 & 5.5 & 3.0 & 50.9 & 19.8 & 0.0 & 5.0 & 8.0 & 4.3 \\
\hline Dead Coral & DC & 0.0 & 0.0 & 0.0 & 0.0 & 0.0 & 0.0 & 0.0 & 0.0 & 0.0 & 0.0 & 0.7 & 0.2 \\
\hline (With Algal Covering) & DCA & 3.0 & 6.5 & 16.3 & 8.6 & 5.5 & 3.0 & 50.9 & 19.8 & 0.0 & 5.0 & 7.3 & 4.1 \\
\hline Algae & & 0.0 & 0.0 & 6.2 & 2.1 & 0.0 & 0.0 & 11.5 & 3.8 & 0.0 & 2.0 & 2.1 & 1.4 \\
\hline Macroalgae & MA & 0.0 & 0.0 & 0.4 & 0.1 & 0.0 & 0.0 & 8.3 & 2.8 & 0.0 & 2.0 & 0.0 & 0.7 \\
\hline Turf Algae & TA & 0.0 & 0.0 & 0.8 & 0.3 & 0.0 & 0.0 & 0.7 & 0.2 & 0.0 & 0.0 & 0.0 & 0.0 \\
\hline Coraline Algae & $\mathrm{CA}$ & 0.0 & 0.0 & 0.0 & 0.0 & 0.0 & 0.0 & 0.0 & 0.0 & 0.0 & 0.0 & 0.0 & 0.0 \\
\hline Halimeda & HA & 0.0 & 0.0 & 0.6 & 0.2 & 0.0 & 0.0 & 0.9 & 0.3 & 0.0 & 0.0 & 1.2 & 0.4 \\
\hline Algal Assemblage & AA & 0.0 & 0.0 & 4.4 & 1.5 & 0.0 & 0.0 & 1.6 & 0.5 & 0.0 & 0.0 & 0.9 & 0.3 \\
\hline Other Fauna & & 3.5 & 5.5 & 16.8 & 8.6 & 2.5 & 0.0 & 3.2 & 1.9 & 4.0 & 29.5 & 10.2 & 14.6 \\
\hline Soft Coral & $\mathrm{SC}$ & 0.0 & 2.5 & 14.1 & 5.5 & 2.5 & 0.0 & 0.0 & 0.8 & 0.0 & 0.0 & 4.3 & 1.4 \\
\hline Sponge & SP & 3.5 & 0.0 & 1.5 & 1.7 & 0.0 & 0.0 & 2.0 & 0.7 & 2.0 & 2.5 & 4.3 & 2.9 \\
\hline Zoanthid & $\mathrm{ZO}$ & 0.0 & 0.0 & 0.8 & 0.3 & 0.0 & 0.0 & 0.0 & 0.0 & 0.0 & 0.0 & 1.5 & 0.5 \\
\hline Others & OT & 0.0 & 3.0 & 0.4 & 1.1 & 0.0 & 0.0 & 1.2 & 0.4 & & 27.0 & 0.0 & 9.7 \\
\hline Abiotic & & 72.0 & 75.5 & 50.0 & 65.8 & 70.5 & 43.8 & 0.0 & 38.1 & $\begin{array}{r}24 . \\
3\end{array}$ & 14.0 & 0.0 & 12.8 \\
\hline Sand & $S$ & $69.5^{\prime}$ & 75.5 & 50.0 & 65.0 & 0.0 & 0.0 & 0.0 & 0.0 & 3.5 & 1.0 & 0.0 & 1.5 \\
\hline Rubble & $\mathrm{R}$ & 2.5 & 0.0 & 0.0 & 0.8 & 70. & 43.8 & 0.0 & 38.1 & 20.8 & 13.0 & 0.0 & 11.3 \\
\hline Silt & SI & 0.0 & 0.0 & 0.0 & 0.0 & 0.0 & 0.0 & 0.0 & 0.0 & 0.0 & 0.0 & 0.0 & 0.0 \\
\hline Water & WA & 0.0 & 0.0 & 0.0 & 0.0 & 0.0 & 0.0 & 0.0 & 0.0 & 0.0 & 0.0 & 0.0 & 0.0 \\
\hline Rock & RCK & 0.0 & 0.0 & 0.0 & 0.0 & 0.0 & 0.0 & 0.0 & 0.0 & 0.0 & 0.0 & 0.0 & 0.0 \\
\hline
\end{tabular}

Beberapa rekomendasi dalam pengelolaan ekosistem terumbu karang antara lain adalah perlindungan terhadap ikan-ikan herbivora, pengurangan runoff dari daratan dan perlindungan terhadap terumbu karang pesisir. Meskipun fase pergantian pada suatu terumbu karang dari komunitas yang didominasi oleh karang menjadi komunitas yang 
didominasi oleh alga telah dihubungkan sebagai akibat dari peningkatan ketersediaan nutrien akibat eutrofikasi dan turunnya kelimpahan herbivora akibat overfishing dan penyakit, faktor-faktor ini sangat jarang dimanipulasi secara bersamaan. Selain itu, juga sangat sedikit penelitian yang mengkaji pengaruh fa ktor-faktor terse but terhadap benthik, filamentous cyanobacteria (blue-green algae) dan juga makroalga. Thacker et al. (2001) telah menggunakan kombinasi dari herbivora yang dikurung secara ekslusif dan pengayaan nutrien untuk memanipulasi kelimpahan herbivora dan ketersediaan nutrien, dan mengukur pengaruh perlakuan ini terhadap struktur komunitas makroalga dan cyanobacteria. Pada perlakuan tanpa ada kurungan, penutupan permukaan oleh cyanobacteria Tolypothrix sp. menurun, sedang penutupan permukaan oleh cyanobacteria Oscillatoria spp. meningkat. Penutupan cyanobacteria menurun pada perlakuan penutupan sebagian dan penutupan Tolypothrix sp. menurun lebih tajam pada penutupan seluruhnya. Lebih rendahnya penutupan dan biomassa cyanobacteria berhubungan dengan lebih tingginya penutupan dan biomassa makroalga. Spesies Dictyota bartayresnia mendominasi penutupan sebagian, sedangkan Padina tenuis dan Tolypiocladia glomerulata menempel pada penutupan seluruhnya. Uji palatabilitas menunjukkan bahwa herbivora eksklusif merubah komposisi spesies makroalga dari spesies yang relatif tidak enak (unpalatability) menjadi yang relatif enak (palatability). Pengayaan yang diinteraksikan dengan ekslusif herbivora meningkatkan perubahan dalam penutupan $D$. bartayresiana pada perlakuan yang tidak dikurung dan dikurung penuh, namun tidak memberikan pengaruh dalam biomassa akhir $D$. bartayresiana selama pengamatan. pengayaan nutrien tidak memberikan pengaruh secara nyata dalam penutupan atau biomassa untuk semua taksa. Hasil penelitian ini memberikan bukti akan pentingnya peranan herbivora dalam menentukan struktur komunitas di terumbu karang dan palatabilitas dari alga yang dominan, demikian juga halnya dengan pertumbuhan alga akibat pengayaan nutrien akan sangat menentukan kemampuan pergantian fase menjadi komunitas yang didominasi oleh alga.

\section{Kesimpulan}

Kondisi terumbu karang di Pulau Payung adalah tergolong baik dengan tutupan karang keras 67\%, sedangkan di Pulau Pari tergolong sedang (36\%) dan Pulau Lancang tergolong buruk (15\%). Tutupan tersebut berkorelasi dengan densitas zooxanthellae.

Terdapat peningkatan tutupan karang keras (hard coral) dengan semakin jauhnya jarak dari daratan utama, Pulau Jawa. Demikian pula dengan kadar zooxanthellae khususnya pada jenis Goniastrea $S p$ yang dominant di ketiga kawasan.

Uji statistik bentuk hidup hewan benthik antara lokasi yang diamati kondisi terumbu karangnya memperlihatkan bahwa perbedaan nyata ditemukan untuk kategori Hard Coral (Non-Acropora) antara Pulau Payung dengan Pulau Lancang dan untuk kategori Abioticantara Pulau Payung dengan Pulau Lancang.

\section{Daftar Pustaka}

Birkeland, C. (1997). Life and death of coral reefs. Chapman and Hall. International Thomson Publishing, New York, Washington.

Damar, A. (2003). Effect of enrichment on nutrient dynamics, phytoplankton dynamics and productivity in Indonesian tropical waters:a comparison between Jakarta Bay, Lampung Bay and Semangka Bay (in English). Dissertation zur erlangung des doktorgrades der mathematics-natuwissenschaftlichen fakultat der Christian-Alberchts Universitat. On line dissertation dikunjungi tanggal 16 September 2003.

Edy Rudi dan Pujiono W.P. 2004. Distribusi Nutrien dan Efeknya Terhadap Status Tropik Perairan Teluk Jakarta. Forum Diskusi Mahasiswa pascasarjana PS. Kelautan IPB (Tidak dipublikasi).

English S, Wilkinson C, Baker V. 1997. Survey manual for tropical marine resources.

Townsville: Australian Institute of Marine Science.

Gee H. 1999. The coral challenge. Di dalam: Nature science update, [14 Maret 2004].

McCook, L.J. and Price LR. (1997). Macroalgal distribution on the Grear Barrier Reef : A review of pattern and cause In:ed)Proc.The Great Barrier reef :Science, Use and Management, A Nat.Conference, November 1996, Townsville.GBRMPA, Townsville, : 37-46.

McCook LJ, Tompa J, Diaz-Pulilo G. 2001. Competition between corals and algae on coral reefs: a review of evidence and mechanism. Coral reef(19): 400- 
417

Potts T. 2002. Aquarius mission summary .. [27 Maret 2004].

Thacker, R.W., D.W.Ginsburg and V,J.Paul (2001). Effect of herbivore exclusion and nutrient enrichment on coral reef macroalgae and cyanobacteria. Coral reefs 19: 318-329.
Veron JEN. 1995. Coral in space and time. Townsville: Australian Institute of Marine Science.

Wyrtki K. 1961. Physical Oceanography of the South East Asia Waters. NAGA Rep. 2. California: Scripps Inst. Of Oceanography La Jolla. 